\title{
Coagulase and protein A polymorphisms do not contribute to persistence of nasal colonisation by Staphylococcus aureus
}

\author{
A. VAN BELKUM, N. H. RIEWARTS ERIKSEN*, MARLY SIJMONS, W. VAN LEEUWEN, \\ MARJOLEIN VAN DEN BERGH, JAN KLUYTMANS, F. ESPERSEN* and H. VERBRUGH
}

Department of Bacteriology, University Hospital Dijkzigt, Dr Molewaterplein 40, 3015 GD Rotterdam. The Netherlands and *Statens Seruminstitut, Staphylococcus Laboratory, Artillerivej 5, DK-2300 Copenhagen S, Denmark

\begin{abstract}
The nasal carriage rate of Staphylococcus aureus was examined in a longitudinal study of 31 healthy Danish volunteers. Each person was classified as persistent $(>8$ positive cultures from 10 examinations), an intermittent carrier (50-80\% positive cultures) or an ocassional carrier (positive cultures on $10-40 \%$ of ocassions only). One hundred and twenty strains from these persons were subjected to phage typing and random amplification of polymorphic DNA (RAPD) analysis. Phage and RAPD typing were in close agreement. RAPD confirmed the spread of a particular $S$. aureus clone (phage type 95) throughout Denmark. However, no common genotype or phenotype characteristics of $S$. aureus that could separate persistent from intermittent or incidental colonisers were identified. The immunoglobulin binding protein $A$ and the prothrombin binding coagulase protein are both putative $S$. aureus virulence or defence factors. Analysis of polymorphisms in the variable repeat regions in the genes for these proteins showed no correlation between the number of repeat units and, consequently, the protein structure with the ability of strains to persist in the human nasal mucosa. The amount of protein A, detectable by its IgG binding activity, appeared not to be correlated to persistence of carriage. Thus protein $A$ and coagulase gene polymorphisms do not seem to play a significant role in the propensity of $S$. aureus to colonise human nasal epithelium. Furthermore, based on the genetic heterogeneity encountered among the $S$. aureus strains it is suggested that within the current study population, no single clonal lineage of $S$. aureus has increased capability to colonise the human nasal epithelium.
\end{abstract}

\section{Introduction}

Nasal carriage of Staphylococcus aureus can be a precursor of severe post-operative complications in surgical patients [1]. For example, in patients who undergo thoracic surgery, a subsequent surgical wound infection with $S$. aureus can be a reason for a prolonged stay in hospital, as well as increased morbidity and even mortality $[2,3]$. To prevent postoperative complications, patients may be treated preoperatively by nasal application of antibiotic-containing ointments. However, examination of the ways in which $S$. aureus colonises the nasal epithelium may produce new approaches to the elimination of colonisation. How it successfully colonises human epithelium is still largely unknown, although many factors relating to adhesion have been described previously [4-6]. To

Received 12 Aug. 1996; accepted 23 Aug. 1996.

Corresponding author: Dr A. van Belkum. evaluate new therapeutic approaches for the elimination of nasal carriage, the molecular basis of persistent colonisation needs to be resolved.

In the present study individuals who were persistently or intermittently colonised with $S$. aureus were identified by longitudinal microbiological follow-up. The strains were typed to identify common genotypic and phenotypic denominators. Genetic polymorphisms in two genes encoding proteins that protrude from the bacterial surface and are thought to play a role in the spread or pathogenicity of $S$. aureus, or both, were determined to elucidate the role of these proteins in epithelial colonisation.

\section{Materials and methods}

Human volunteers

The initial study population comprised 86 female and 18 male healthy, normal volunteers [7]. They were all 
employed at the Statens Seruminstitut (Copenhagen, Denmark), in different departments and buildings. Their median age was 46 (range 23-69) years. Serial nasal swabs were collected over a 19-month period (January 1992-August 1993) by one investigator and by a standardised technique. The left and right anterior nares were swabbed with sterile, dry cotton-wool swabs (Dansu A/S, Ganlose, Denmark) [8]. The entire anterior nares were swabbed by rubbing twice around the nostril, applying an even and uninterrupted pressure. When cultures were consistently positive or positive in nine out of 10 assays, the individual was identified as a persistent carrier (carriage index 10 or 9 ). When 8,7 or 6 cultures out of 10 were positive, the individual was described as an intermittent carrier. Lower scores indicated sporadic carriage.

\section{Cultivation of $S$. aureus from nasal swabs}

Swabs were inoculated directly on to $5 \%$ blood agar and mannitol salt agar [6]. The swabs were then incubated in broth enrichment medium with $\mathrm{NaCl} 6.5 \%$ at $37^{\circ} \mathrm{C}$ for $18 \mathrm{~h}$ or in Stuart's transport medium for 7 days at $4^{\circ} \mathrm{C}$ [9]. All solid media were incubated at $37^{\circ} \mathrm{C}$ for $16 \mathrm{~h}$, after which plates were placed at room temperature and left for up to 6 days.

\section{Identification of $S$. aureus}

Colonies were selected on the basis of morphological characteristics, checked by gram-stained films and tested for catalase and coagulase production. Coagulase production was assayed by the citrate-plasma tube technique [8].

\section{Phage typing}

The method of Blair and Williams was used [10]. The phages comprised the current international set with two additional local Danish phages. Bacteria were assayed by application of routine test dilutions (RTD) of the phages. When strains appeared to be non-typable under these conditions, $100 \times$ RTD and $1000 \times$ RTD were also tested. Subdivision into groups was as described by Parker [11].

\section{RAPD analysis}

Bacteria were grown in suspension in brain heart infusion (BHI) broth for $18 \mathrm{~h}$ at $37^{\circ} \mathrm{C}$. A volume of $c$. $100 \mu \mathrm{l}$ of a bacterial pellet was suspended in $150 \mu \mathrm{l}$ of $25 \mathrm{~mm}$ Tris- $\mathrm{HCl}, \mathrm{pH} 8.0,50 \mathrm{~mm}$ glucose and $10 \mathrm{~mm}$ EDTA. Lysostaphin ( $75 \mu \mathrm{l}$ of a $100 \mu \mathrm{l} / \mathrm{ml}$ solution) was added and the mixture was incubated at $37^{\circ} \mathrm{C}$ for $1 \mathrm{~h}$. Spheroplasts were lysed by the addition of $1 \mathrm{ml}$ of $4 \mathrm{M}$ guanidinium isothiocyanate, $50 \mathrm{mM}$ Tris- $\mathrm{HCl}, \mathrm{pH}$ 6.4, $3 \mathrm{~mm}$ EDTA, Triton X-100 1\% w/w [12]. To immobilise and purify the DNA, $50 \mu \mathrm{l}$ of a Celite suspension $(0.2 \mathrm{~g} / \mathrm{ml}$; Janssen Pharmaceuticals, Beerse, Belgium) was added. The entire mixture was shaken for $15 \mathrm{~s}$ and incubated at room temperature for $10 \mathrm{~min}$. The pellet was washed once with $1 \mathrm{ml}$ of lysis buffer, twice with lysis buffer without EDTA and Trinton X100 , twice with ethanol $70 \%$ in water and finally once with acetone. Between 100 and $400 \mu \mathrm{l}$ of $10 \mathrm{mM}$ Tris$\mathrm{HCl}, \mathrm{pH} 8.0,1 \mathrm{mM}$ EDTA were added and DNA was eluted by incubation at $56^{\circ} \mathrm{C}$ for $10 \mathrm{~min}$. The supernate containing the DNA was separated from the Celite by centrifugation. Stock solutions of bacterial DNA were adjusted to a concentration of $5 \mathrm{ng} / 10 \mu \mathrm{l}$ and stored at $-20^{\circ} \mathrm{C}$.

PCR was performed in a buffer system containing $10 \mathrm{mM}$ Tris- $\mathrm{HCl}, \mathrm{pH} 9.0,50 \mathrm{mM} \mathrm{KCl}, 2.5 \mathrm{mM} \mathrm{MgCl}_{2}$, gelatin $0.01 \%$ Triton $\mathrm{X}-100 \quad 0.1 \%, 0.2 \mathrm{mM}$ of the respective deoxynucleotide triphosphates, 50 pmoles of primer and 0.2 units of the Tth polymerase (Supertaq; HT Biotechnology, Cambridge), to which DNA was added (5 ng for each amplification). The PCR mixtures were overlaid with $100 \mu \mathrm{l}$ of mineral oil. Cycling was performed in Biomed PCR machine (Model 60) and consisted of the following steps: predenaturation at $94^{\circ} \mathrm{C}$ for $4 \mathrm{~min}$ and 35 cycles of $1 \mathrm{~min}$ at $94^{\circ} \mathrm{C}, 1 \mathrm{~min}$ at $25^{\circ} \mathrm{C}$ and $2 \mathrm{~min}$ at $74^{\circ} \mathrm{C}$. The primers used to discriminate $S$. aureus strains were 1 (GGTTGGGTGAGAATTCACG), 7 (GTGGATGCGA) and ERIC2 (AAGTAAGTGACTGGGGTGAGCG) [13-15].

\section{Electrophoresis}

Amplification products were separated by electrophoresis in agarose $1 \%$ gels, $5 \mathrm{~mm}$ thick (Hispanagar, Sphaero Q, Leiden, the Netherlands). Gels were run in $0.5 \times \mathrm{TBE}$ at a constant current of $100 \mathrm{~mA}$ for $3 \mathrm{~h}$. Before electrophoresis, samples were mixed with a $5 \times$ concentrated layer mix consisting of glycerol $50 \%$ in water and bromophenol blue $0.8 \mathrm{mg} / \mathrm{ml} ; 35 \mu \mathrm{l}$ of the amplified material were loaded on to the gel and a mol.wt marker was run in parallel with the RAPD samples. Gels were stained before electrophoresis by addition of $10 \mu \mathrm{l}$ of ethidium bromide $(10 \mathrm{mg} / \mathrm{ml})$ to a total volume of $300 \mathrm{ml}$ of $0.5 \times \mathrm{TBE}$. Gels were photographed with a Polaroid MP4 Landcamera and Polaroid 57 High Speed films; the exposure time was 0.125-0.25 s (diaphragm F5.6). Banding patterns visualised in this manner were indexed by Roman lettering. Even single band differences led to the definition of a novel type. This is based on the percentile effect of a single band difference between banding patterns comprising 6-15 different DNA fragments. In this way all the bacterial isolates were identified by a three-letter code.

\section{Protein A gene PCR}

Length polymorphisms in the staphylococcal protein A gene were determined by PCR essentially as described before [16]. Briefly, the repetitive region within the gene was amplified with oligonucleotide primers 
with the following DNA sequences: 5'-TGTAAAACGACGGCCAGTGCTAAAAAGCTAAACGATGC- ${ }^{\prime}$ and 5'-CAGGAAACAGCTATGACCCCACCAAATACAGTTGTTACC-3'. After PCR, DNA was cleaved with the restriction endonuclease RsaI (Boehringer Mannheim, Germany) and restriction fragment length polymorphisms (RFLP) were determined by electrophoresis in Nusieve GTG agarose 3\% gels (Biozymn, the Netherlands) run in $0.5 \times \mathrm{TBE}$. The number of repetitive units present in the genes' variable region was estimated in comparison with mol.wt markers (100 bp ladder; Pharmacia, Gouda, The Netherlands).

\section{Coagulase gene PCR}

The analysis was aimed at the $3^{\prime}$ end of the coagulase gene. Amplification was done with primers COAG2 and COAG3 [17]. The DNA sequences of these primers are 5'-CGAGACCAAGATTCAACAAG-3' and 5'AAAGAAAACCACTCACATCA-3'. DNA (5 ng) was amplified by 40 cycles of $1 \mathrm{~min}$ at $95^{\circ} \mathrm{C}, 1 \mathrm{~min}$ at $52^{\circ} \mathrm{C}$ and $1 \mathrm{~min}$ at $74^{\circ} \mathrm{C}$, after a predenaturation period of $4 \mathrm{~min}$ at $95^{\circ} \mathrm{C}$. The PCR mixture was as described above. The amplification product $(10 \mu \mathrm{l})$ was digested with the restriction endonuclease $A l u \mathrm{I}$ (Boehringer Mannheim, Germany). Restriction fragments were analysed as described above for the protein A gene analysis. Digests were analysed with respect to the overall number of 81-bp repeats detectable and in regard to the actual RFLP pattern, in comparison with a 100-bp mol. wt marker (Pharmacia).

\section{Protein A assay by $\operatorname{Ig} G$ binding}

Bacteria were grown overnight on $5 \%$ blood agar (Statens Seruminstitut, Copenhagen, Denmark). Between five and 10 colonies were suspended in phosphate-buffered saline, $\mathrm{pH} 7.4$ (PBS), and the optical density $(540 \mathrm{~nm})$ was adjusted to 0.4 . This represented a bacterial density of $c$. $(2-3) \times 10^{8} \mathrm{cfu} / \mathrm{ml}$. Bacteria were diluted to working concentrations of $5 \times 10^{6}$ $\mathrm{cfu} / \mathrm{ml}$ of PBS; $100 \mu \mathrm{l}$ of this suspension were used for coating Nunc Immunoplates (A/S Nunc, Roskilde, Denmark); after $1 \mathrm{~h}$ at $20^{\circ} \mathrm{C}$, the plates were washed three times with PBS. Remaining binding sites were blocked by incubation for $1 \mathrm{~h}$ at $20^{\circ} \mathrm{C}$ and overnight incubation at $4^{\circ} \mathrm{C}$ with $100 \mu \mathrm{l}$ of PBS containing Triton $\mathrm{X}-1000.1 \%$ (PBST). After three washes, $100 \mu \mathrm{l}$ of peroxidase-conjugated rabbit anti-mouse immunoglobulins (DAKO, Glostrup, Denmark) diluted in PBST were applied to each well and incubated for $1 \mathrm{~h}$ at $20^{\circ} \mathrm{C}$. After five washes in PBST the plates were stained for $30 \mathrm{~min}$ at room temperature in the dark with citric acid buffer ( $\mathrm{pH} 5.0$ ) containing OPD (Kem-EnTec, Copenhagen, Denmark) and hydrogen peroxide $3 \%$. The colour reaction was stopped by the addition of $100 \mu \mathrm{l}$ of $1 \mathrm{~N} \mathrm{H}_{2} \mathrm{SO}_{4}$. All bacterial strains were tested in triplicate and the reference strain S. aureus Cowan I was included on each microtitration plate. The IgG binding was expressed as the ratio of the mean OD measured for the strain under investigation and that determined for $S$. aureus Cowan I strain.

\section{Results}

\section{Carrier rates}

Of the 31 individuals enrolled in the study, six had $S$. aureus cultured from their nares on every occasion. An equal number were culture-positive in nine out of 10 nasal swabs. The group comprised 12 persistent, nine intermittent and 10 ocassional carriers. The general carrier index varied from three to 10 in this group (Table 1). The length of the screening period varied from 8 to 31 months; no major differences were observed between data obtained for left and right nostrils.

\section{Phage types and RAPD analysis}

Results of both phage typing and RAPD analysis are summarised in Table 1. An example of the RAPD data is shown in Fig. 1. The results of both typing strategies were very similar, e.g., RAPD type BBB was identical to phage type 95 ; this occurs relatively frequently. Overall, RAPD identified 25 different genotypes among these $S$. aureus strains. When the number of types encountered in a given individual was plotted against the carriage index, it is seen that in those who were colonised intermittently or occasionally, multiple types were encountered (Table 2). It is also clear that phage typing identified larger numbers of phagovars than RAPD analysis identified genotypes. This may relate to different phage typing results as a consequence of differences in cultivation or bacterial storage [14]. When the RAPD type was plotted against the carriage rate (Fig. 2) genotype $\mathrm{BBB}$ was shown to be prevalent. Also, types AAA, CCC, DDD, EEE, JIH, MLJ, PNC and OOL were encountered in several volunteers.

\section{Variability in coagulase and protein $A$ genes}

Variation in the coagulase gene could be demonstrated at two levels. First, restriction fragment length polymorphism (RFLP) was evident as 12 different banding patterns were observed (Fig. 3). The overall number of repeats was assessed also: this number varied from five to 15 (Table 1). Fig. 4 shows the comparable RFLP results obtained with the analysis of the protein $A$ gene. The number of repeat units as estimated by gel electrophoresis varied from three to 11 . There appeared to be a clear overlap between the coagulase and protein A typing data. The numbers of repeats detected in both genes were not correlated. A large number of repeats in the protein A gene was found to be accompanied by variable repeat numbers in the coagulase gene and vice versa. When the RAPD results and data obtained by coagulase and protein A gene mapping were compared, it was clear that, as a single technique, RAPD provided optimal resolution: 25 distinct genotypes were identi- 
Table 1. Carriage characteristics and phenotypic and molecular typing data of S. aureus strains

\begin{tabular}{|c|c|c|c|c|c|c|c|c|c|}
\hline Strain no. & $\begin{array}{c}\text { Patient } \\
\text { no. }\end{array}$ & $\begin{array}{c}\text { Carriage } \\
\text { index }\end{array}$ & Nostril & $\begin{array}{l}\text { Date of } \\
\text { isolation }\end{array}$ & $\begin{array}{l}\text { Phage } \\
\text { type }\end{array}$ & $\begin{array}{l}\text { RAPD } \\
\text { type }\end{array}$ & $\begin{array}{c}\text { Number of } \\
\text { Protein A } \\
\text { repeats }\end{array}$ & $\begin{array}{l}\text { Relative } \\
\text { amount of } \\
\text { protein } \mathrm{A}\end{array}$ & $\begin{array}{l}\text { Coagulase } \\
\text { gene type }\end{array}$ \\
\hline \multicolumn{10}{|c|}{ Persistent carriers } \\
\hline 1 & 17 & 10 & $\mathrm{R}$ & 07-01-1992 & 793 & AAA & 7 & 0 & $12 \mathrm{~A}$ \\
\hline 2 & 17 & 10 & $\mathrm{~L}$ & $31-08-1992$ & 793 & AAA & 7 & 0 & $12 \mathrm{~A}$ \\
\hline 3 & 17 & 10 & $\mathrm{R}$ & 14-02-1994 & 811 & $\mathrm{BBB}$ & 9 & 0 & $14 \mathrm{~B}$ \\
\hline 4 & 17 & 10 & $\mathrm{R}$ & $02-05-1994$ & 313 & $\mathrm{BBB}$ & 9 & 1 & $14 \mathrm{~B}$ \\
\hline 5 & 17 & 10 & $\mathbf{R}$ & $15-08-1994$ & 793 & AAA & 7 & 0 & $12 \mathrm{~A}$ \\
\hline 6 & 17 & 10 & $\mathbf{L}$ & 15-08-1994 & 583 & $\mathrm{AAA}$ & 7 & 0 & $12 \mathrm{~A}$ \\
\hline 7 & 19 & 10 & $\mathrm{R}$ & $07-01-1992$ & 811 & $\mathrm{BBB}$ & 9 & 1 & $14 B$ \\
\hline 8 & 19 & 10 & $\mathrm{~L}$ & 27-04-1992 & 692 & BBB & 9 & 1 & 14B \\
\hline 9 & 19 & 10 & $\mathrm{R}$ & $31-08-1992$ & 692 & $\mathrm{BBB}$ & 9 & 1 & $14 \mathrm{~B}$ \\
\hline 10 & 19 & 10 & $\mathrm{~L}$ & $19-10-1992$ & 191 & $\mathrm{BBB}$ & 9 & 1 & $14 \mathrm{~B}$ \\
\hline 11 & 19 & 10 & $\mathrm{R}$ & $09-08-1993$ & 811 & $\mathrm{BBB}$ & 9 & 1 & $14 \mathrm{~B}$ \\
\hline 12 & 19 & 10 & $\mathrm{R}$ & $14-02-1994$ & 811 & $\mathrm{BBB}$ & 9 & 1 & $14 \mathrm{~B}$ \\
\hline 13 & 25 & 10 & $\mathrm{R}$ & $07-01-1992$ & 232 & $\mathrm{CCC}$ & 10 & 93 & $9 \mathrm{C}$ \\
\hline 14 & 25 & 10 & $\mathrm{R}$ & 24-02-1992 & 292 & $\mathrm{CCC}$ & 10 & 137 & $9 \mathrm{C}$ \\
\hline 15 & 25 & 10 & $\mathrm{R}$ & 18-04-1993 & 232 & $\mathrm{CCC}$ & 10 & 99 & $9 \mathrm{C}$ \\
\hline 16 & 25 & 10 & $\mathrm{~L}$ & $09-08-1993$ & 222 & $\mathrm{CCC}$ & 10 & 131 & $9 \mathrm{C}$ \\
\hline 17 & 25 & 10 & $\mathrm{~L}$ & $02-05-1994$ & 232 & $\mathrm{CCC}$ & 10 & 134 & $9 \mathrm{C}$ \\
\hline 18 & 25 & 10 & $\mathrm{R}$ & $15-08-1994$ & 232 & $\mathrm{CCC}$ & 10 & 115 & $9 \mathrm{C}$ \\
\hline 19 & 51 & 10 & $\mathrm{~L}$ & $24-02-1992$ & 641 & DDD & 4 & 92 & $9 \mathrm{C}$ \\
\hline 20 & 51 & 10 & $\mathrm{~L}$ & 09-03-1992 & 641 & DDD & 4 & 64 & $9 \mathrm{C}$ \\
\hline 21 & 51 & 10 & $\mathrm{R}$ & 27-04-1992 & 641 & DDD & 4 & 80 & $9 \mathrm{C}$ \\
\hline 22 & 51 & 10 & $\mathrm{~L}$ & 18-04-1993 & 641 & DDD & 4 & 83 & $9 \mathrm{C}$ \\
\hline 23 & 51 & 10 & $\mathrm{R}$ & 14-02-1994 & 641 & DDD & 4 & 87 & $9 \mathrm{C}$ \\
\hline 24 & 51 & 10 & $\mathrm{R}$ & $02-05-1994$ & 641 & DDD & 4 & 62 & $9 \mathrm{C}$ \\
\hline 25 & 68 & 10 & $\mathrm{~L}$ & 24-02-1992 & 191 & EEE & 7 & 93 & $8 \mathrm{D}$ \\
\hline 26 & 68 & 10 & $\mathrm{R}$ & 09-03-1992 & 191 & EEE & 7 & 106 & $8 \mathrm{D}$ \\
\hline 27 & 68 & 10 & $\mathrm{R}$ & 27-04-1992 & 191 & $\mathrm{EEE}$ & 7 & 101 & $8 \mathrm{D}$ \\
\hline 28 & 68 & 10 & $\mathrm{R}$ & $25-06-1992$ & 192 & $\mathrm{EEE}$ & 7 & 89 & $8 \mathrm{D}$ \\
\hline 29 & 68 & 10 & $\mathrm{R}$ & $31-08-1992$ & 191 & EEE & 7 & 93 & $8 \mathrm{D}$ \\
\hline 30 & 68 & 10 & $\mathrm{R}$ & $19-10-1992$ & 581 & EEE & 7 & 93 & $8 \mathrm{D}$ \\
\hline 31 & 120 & 10 & $\mathrm{~L}$ & $19-10-1992$ & 692 & $\mathrm{BBB}$ & 5 & 21 & 14B \\
\hline 32 & 120 & 10 & $\mathrm{R}$ & 06-01-1993 & 692 & $\mathrm{BBB}$ & 5 & 16 & $14 \mathrm{~B}$ \\
\hline 33 & 120 & 10 & $\mathrm{R}$ & 18-04-1993 & 811 & $\mathrm{BBB}$ & 5 & 15 & $14 \mathrm{~B}$ \\
\hline 34 & 120 & 10 & $\mathrm{~L}$ & $01-11-1993$ & 811 & $\mathrm{BBB}$ & 5 & 17 & $14 \mathrm{~B}$ \\
\hline 35 & 120 & 10 & $\mathrm{~L}$ & 02-05-1994 & 811 & $\mathrm{BBB}$ & 5 & 22 & $14 \mathrm{~B}$ \\
\hline 36 & 120 & 10 & $\mathrm{~L}$ & $15-08-1994$ & 811 & $\mathrm{BBB}$ & 5 & 16 & 14B \\
\hline 37 & 26 & 9 & $\mathrm{R}$ & $07-01-1992$ & 292 & $\mathrm{FFC}$ & 6 & 11 & $8 \mathrm{D}$ \\
\hline 38 & 26 & 9 & $\mathrm{R}$ & 24-02-1992 & 232 & $\mathrm{FFC}$ & 6 & 15 & $8 \mathrm{D}$ \\
\hline 39 & 26 & 9 & $\mathrm{~L}$ & $19-10-1992$ & 232 & FFC & 6 & 10 & $8 \mathrm{D}$ \\
\hline 40 & 26 & 9 & $\mathrm{R}$ & $01-11-1993$ & 192 & FFC & 7 & 58 & $8 \mathrm{D}$ \\
\hline 41 & 26 & 9 & $\mathrm{~L}$ & $14-02-1994$ & 192 & $\mathrm{FFC}$ & 6 & 27 & $8 \mathrm{D}$ \\
\hline 42 & 26 & 9 & $\mathrm{R}$ & 02-05-1994 & 232 & $\mathrm{FFC}$ & 7 & 48 & $8 \mathrm{D}$ \\
\hline 43 & 53 & 9 & $\mathrm{~L}$ & 24-02-1992 & 793 & GGF & - & 0 & $5 \mathrm{E}$ \\
\hline 44 & 53 & 9 & $\mathrm{~L}$ & 09-03-1992 & 641 & DDD & 4 & 94 & $9 \mathrm{C}$ \\
\hline 45 & 53 & 9 & $\mathrm{R}$ & $31-08-1992$ & 793 & AAA & 7 & 0 & $12 \mathrm{~A}$ \\
\hline 46 & 53 & 9 & $\mathrm{R}$ & 09-08-1993 & 542 & GGG & 10 & 12 & $10 \mathrm{~F}$ \\
\hline 47 & 53 & 9 & $\mathrm{R}$ & 01-11-1993 & 693 & GGG & 10 & 21 & $10 \mathrm{~F}$ \\
\hline 48 & 53 & 9 & $\mathrm{~L}$ & $15-08-1994$ & 542 & GGG & 9 & 12 & $10 \mathrm{~F}$ \\
\hline 49 & 58 & 9 & $\mathrm{R}$ & $24-02-1992$ & 191 & $\mathrm{EEE}$ & 9 & 93 & $10 \mathrm{G}$ \\
\hline 50 & 58 & 9 & $\mathrm{R}$ & $19-10-1992$ & 191 & EEE & 9 & 95 & $10 \mathrm{G}$ \\
\hline 51 & 58 & 9 & $\mathrm{R}$ & $01-11-1993$ & 191 & $\mathrm{EEE}$ & 9 & 98 & $10 \mathrm{G}$ \\
\hline 52 & 78 & 9 & $\mathrm{R}$ & $24-02-1992$ & 213 & $\mathrm{IHC}$ & 7 & 86 & $9 \mathrm{H}$ \\
\hline 53 & 78 & 9 & $\mathrm{R}$ & $06-01-1993$ & 812 & $\mathrm{IHC}$ & 7 & 111 & $9 \mathrm{H}$ \\
\hline 54 & 84 & 9 & $\mathrm{R}$ & 09-03-1992 & 692 & $\mathrm{JIH}$ & 8 & 7 & $15 \mathrm{I}$ \\
\hline 55 & 84 & 9 & $\mathrm{R}$ & 18-04-1993 & 692 & $\mathrm{JIH}$ & 7 & 10 & $15 \mathrm{I}$ \\
\hline 56 & 84 & 9 & $\mathrm{R}$ & $01-11-1993$ & 811 & BBB & 5 & 24 & $14 B$ \\
\hline 57 & 84 & 9 & $\mathrm{~L}$ & 15-08-1994 & 292 & KJI & 9 & 74 & $9 \mathrm{C}$ \\
\hline 58 & 126 & 9 & $\mathrm{R}$ & 19-10-1992 & 793 & $\mathrm{LKC}$ & 8 & 92 & $11 \mathrm{~N}$ \\
\hline 59 & 126 & 9 & $\mathrm{R}$ & 18-04-1993 & 812 & $\mathrm{BBB}$ & 7 & 96 & $14 \mathrm{~B}$ \\
\hline 60 & 126 & 9 & $\mathrm{~L}$ & 15-08-1994 & 811 & $\mathrm{BBB}$ & 7 & 104 & $14 \mathrm{~B}$ \\
\hline \multicolumn{10}{|c|}{ Intermittent carriers } \\
\hline 61 & 85 & 8 & $\mathrm{R}$ & 24-02-1992 & 311 & $\mathrm{JIH}$ & 7 & 66 & $15 \mathrm{I}$ \\
\hline 62 & 85 & 8 & $\mathrm{~L}$ & 09-03-1992 & 812 & $\mathrm{BBB}$ & 8 & 0 & $14 \mathrm{~B}$ \\
\hline 63 & 85 & 8 & $\mathrm{~L}$ & $06-01-1993$ & 232 & $\mathrm{BBB}$ & 8 & 0 & $14 \mathrm{~B}$ \\
\hline 64 & 85 & 8 & $\mathrm{~L}$ & 15-08-1994 & 362 & $\mathrm{JIH}$ & 9 & 0 & $15 \mathrm{I}$ \\
\hline 65 & 122 & 7 & $\mathrm{~L}$ & 06-01-1993 & 692 & JIH & 9 & 0 & $15 \mathrm{I}$ \\
\hline 66 & 122 & 7 & $\mathrm{~L}$ & 01-11-1993 & 311 & $\mathrm{JIH}$ & 9 & 31 & $15 \mathrm{I}$ \\
\hline 67 & 122 & 7 & $\mathrm{R}$ & $14-02-1994$ & 332 & $\mathrm{JIH}$ & 9 & 23 & 151 \\
\hline 68 & 122 & 7 & $\mathrm{~L}$ & 14-02-1994 & 311 & $\mathrm{JIH}$ & 9 & 25 & $15 \mathrm{I}$ \\
\hline 69 & 2 & 6 & $\mathrm{~L}$ & $25-06-1992$ & 813 & $\mathrm{BBB}$ & 9 & 1 & $14 \mathrm{~B}$ \\
\hline 70 & 2 & 6 & $\mathrm{R}$ & $19-10-1992$ & 691 & $\mathrm{BBB}$ & 9 & 1 & 14B \\
\hline 71 & 2 & 6 & $\mathrm{~L}$ & 18-04-1993 & 793 & AAA & 7 & 0 & $12 \mathrm{~A}$ \\
\hline 72 & 2 & 6 & $\mathrm{R}$ & 14-02-1994 & 811 & BBB & 9 & 1 & $14 \mathrm{~B}$ \\
\hline
\end{tabular}


Table 1. (continued)

\begin{tabular}{|c|c|c|c|c|c|c|c|c|c|}
\hline Strain no. & $\begin{array}{c}\text { Patient } \\
\text { no. }\end{array}$ & $\begin{array}{c}\text { Carriage } \\
\text { index }\end{array}$ & Nostril & $\begin{array}{l}\text { Date of } \\
\text { isolation }\end{array}$ & $\begin{array}{c}\text { Phage } \\
\text { type }\end{array}$ & $\begin{array}{l}\text { RAPD } \\
\text { type }\end{array}$ & $\begin{array}{c}\text { Number of } \\
\text { Protein A } \\
\text { repeats }\end{array}$ & $\begin{array}{l}\text { Relative } \\
\text { amount of } \\
\text { protein A }\end{array}$ & $\begin{array}{l}\text { Coagulase } \\
\text { gene type }\end{array}$ \\
\hline 73 & 9 & 6 & $\mathrm{R}$ & $25-06-1992$ & 811 & BBB & 5 & 31 & 14B \\
\hline 74 & 9 & 6 & $\mathrm{~L}$ & $19-10-1992$ & 292 & $\mathrm{CCC}$ & 7 & 72 & $9 \mathrm{C}$ \\
\hline 75 & 9 & 6 & L & 01-11-1993 & 233 & $\mathrm{CCC}$ & 7 & 72 & $9 \mathrm{C}$ \\
\hline 76 & 9 & 6 & $\mathrm{R}$ & $15-08-1994$ & 191 & MLJ & 5 & 41 & - \\
\hline 77 & 22 & 6 & $\mathrm{R}$ & $25-06-1992$ & 692 & MLJ & 10 & 46 & $10 \mathrm{G}$ \\
\hline 78 & 22 & 6 & $\mathrm{~L}$ & $15-08-1994$ & $52 / 79 / 80$ & MLJ & 10 & 76 & $10 \mathrm{G}$ \\
\hline 79 & 32 & 6 & $\mathrm{R}$ & $20-01-1992$ & 811 & BBB & 3 & 58 & 14B \\
\hline 80 & 32 & 6 & $\mathrm{R}$ & $25-06-1992$ & 811 & BBB & 3 & 55 & $14 \mathrm{~B}$ \\
\hline 81 & 32 & 6 & $\mathrm{~L}$ & 15-08-1994 & 793 & NMK & 9 & 34 & $9 \mathrm{~J}$ \\
\hline 82 & 46 & 6 & $\mathrm{R}$ & $25-06-1992$ & 291 & OMC & 9 & 103 & $9 \mathrm{H}$ \\
\hline 83 & 46 & 6 & $\mathrm{R}$ & $31-08-1992$ & 292 & OMC & 9 & 99 & $9 \mathrm{H}$ \\
\hline 84 & 20 & 5 & $\mathrm{~L}$ & 09-03-1992 & 562 & PNC & 8 & 2 & $10 \mathrm{G}$ \\
\hline 85 & 20 & 5 & $\mathrm{~L}$ & $27-04-1992$ & 293 & $\mathrm{CCC}$ & 10 & 1 & $9 \mathrm{C}$ \\
\hline 86 & 20 & 5 & $\mathrm{~L}$ & $25-06-1992$ & 811 & BBB & 10 & 1 & $14 \mathrm{~B}$ \\
\hline 87 & 20 & 5 & $\mathrm{~L}$ & $06-01-1993$ & 793 & AAA & 7 & 0 & $12 \mathrm{~A}$ \\
\hline 88 & 113 & 5 & $\mathrm{~L}$ & 09-03-1992 & 692 & JFH & 7 & 62 & 101 \\
\hline 89 & 113 & 5 & $\mathrm{~L}$ & $19-10-1992$ & 811 & BBB & 10 & 1 & $14 \mathrm{~B}$ \\
\hline 90 & 113 & 5 & L & $14-02-1994$ & 631 & $\mathrm{OOL}$ & 9 & 24 & $9 \mathrm{C}$ \\
\hline \multicolumn{10}{|c|}{ Occasional carriers } \\
\hline 91 & 11 & 4 & $\mathrm{~L}$ & $31-08-1992$ & 691 & PPB & 10 & 106 & 9J \\
\hline 92 & 11 & 4 & $\mathrm{R}$ & $01-11-1993$ & 331 & QCC & 7 & 44 & $8 \mathrm{D}$ \\
\hline 93 & 11 & 4 & L & 15-08-1994 & 361 & QCC & 7 & 65 & $8 \mathrm{D}$ \\
\hline 94 & 33 & 4 & $\mathrm{R}$ & $20-01-1992$ & 191 & AAA & 7 & 84 & $12 \mathrm{~A}$ \\
\hline 95 & 33 & 4 & $\mathrm{~L}$ & $09-08-1993$ & 793 & AAA & 7 & 0 & $12 \mathrm{~A}$ \\
\hline 96 & 33 & 4 & $\mathrm{~L}$ & $15-08-1994$ & 231 & $\mathrm{CCC}$ & 11 & 23 & $9 \mathrm{C}$ \\
\hline 97 & 76 & 4 & $\mathrm{~L}$ & $24-02-1992$ & 232 & $\mathrm{CCC}$ & 10 & 86 & $9 \mathrm{C}$ \\
\hline 98 & 76 & 4 & L & $19-10-1992$ & 191 & BBB & 10 & 1 & $14 \mathrm{~B}$ \\
\hline 99 & 76 & 4 & $\mathrm{R}$ & $15-08-1994$ & 641 & OOL & 8 & 7 & $9 \mathrm{C}$ \\
\hline 100 & 80 & 4 & $\mathrm{R}$ & $31-08-1992$ & 232 & $\mathrm{CCC}$ & 11 & 43 & $9 \mathrm{C}$ \\
\hline 101 & 80 & 4 & $\mathrm{~L}$ & $06-01-1993$ & 692 & RNM & 8 & 10 & $15 \mathrm{I}$ \\
\hline 102 & 80 & 4 & $\mathrm{~L}$ & $14-02-1994$ & 811 & BBB & 5 & 12 & $14 \mathrm{~B}$ \\
\hline 103 & 121 & 4 & $\mathrm{~L}$ & $19-10-1992$ & 793 & SMH & 7 & 52 & $10 \mathrm{~F}$ \\
\hline 104 & 121 & 4 & $\mathbf{L}$ & $14-02-1994$ & 811 & BBB & 5 & 2 & $14 \mathrm{~B}$ \\
\hline 105 & 121 & 4 & $\mathbf{R}$ & $14-02-1994$ & 543 & $\mathrm{PNC}$ & 8 & 2 & $10 \mathrm{G}$ \\
\hline 106 & 132 & 4 & $\mathrm{R}$ & $06-01-1993$ & 812 & BBB & 6 & 75 & $14 \mathrm{~B}$ \\
\hline 107 & 132 & 4 & $\mathrm{~L}$ & $09-08-1993$ & 811 & BBB & 6 & 74 & $14 \mathrm{~B}$ \\
\hline 108 & 132 & 4 & $\mathrm{~L}$ & $14-02-1994$ & 793 & PNC & 8 & 2 & $10 \mathrm{G}$ \\
\hline 109 & 12 & 3 & $\mathrm{R}$ & $31-08-1992$ & 691 & LQN & 7 & 24 & - \\
\hline 110 & 12 & 3 & $\mathrm{R}$ & $06-01-1993$ & 632 & OOL & 9 & 17 & $9 \mathrm{C}$ \\
\hline 111 & 12 & 3 & L & 18-04-1993 & 811 & BBB & 5 & 17 & $14 \mathrm{~B}$ \\
\hline 112 & 15 & 3 & $\mathrm{R}$ & $27-04-1992$ & 691 & BBB & 9 & 0 & $14 \mathrm{~B}$ \\
\hline 113 & 15 & 3 & $\mathrm{R}$ & $19-10-1992$ & 793 & TRO & - & 1 & - \\
\hline 114 & 15 & 3 & $\mathrm{~L}$ & $01-11-1993$ & 691 & BBB & 9 & 0 & 14B \\
\hline 115 & 21 & 3 & $\mathrm{R}$ & $10-02-1992$ & 231 & USC & 7 & 19 & $17 \mathrm{~L}$ \\
\hline 116 & 21 & 3 & $\mathrm{R}$ & 09-03-1992 & 232 & $\mathrm{CCC}$ & 10 & 62 & $9 \mathrm{C}$ \\
\hline 117 & 21 & 3 & $\mathrm{R}$ & $18-04-1993$ & 811 & BBB & 6 & 84 & $14 \mathrm{~B}$ \\
\hline 118 & 31 & 3 & $\mathrm{~L}$ & $09-03-1992$ & 232 & $\mathrm{CCC}$ & 11 & 63 & $9 \mathrm{C}$ \\
\hline 119 & 31 & 3 & $\mathrm{~L}$ & $01-11-1993$ & 311 & JFH & 10 & 22 & 101 \\
\hline 120 & 31 & 3 & $\mathrm{~L}$ & $15-08-1994$ & 362 & $\mathrm{JFH}$ & 10 & 8 & $10 \mathrm{I}$ \\
\hline
\end{tabular}

Note: The carriage index is the number of $S$. aureus-positive cultures in 10 attempts to isolate this species from nasal swabs. Either the left (L) or right $(\mathrm{R})$ nostril was analysed; when both nostrils were examined on a single day, the nostril indication is given in bold. Phage types are given in an abbreviated form according to standards applied within the Statens Seruminstitut.

fied. Protein A and coagulase gene RFLP analyses identified nine and 15 types, respectively. However, the overall resolution can be greatly enhanced by combining the datasets (Table 3). As RAPD and coagulase typing results were quite similar, their combination identified a single additional type only. In contrast, the combination of RAPD with protein A types or the combination of protein $\mathrm{A}$ and coagulase types recognised 38 and 35 types, respectively (Table 3 ). This is mainly due to the variability of protein A genes in $S$. aureus strains of otherwise constant genotypic characteristics. It would seem that the protein A gene evolves at a different speed from the coagulase gene or the overall genetic composition as measured by RAPD. For instance, strains of RAPD type BBB could harbour protein $A$ genes varying in repeat number from three to five to 10 units; RAPD genotypes CCC, FFC, GGG, $\mathrm{JIH}$ and JFH displayed a similar protein A gene polymorphism.

When the protein $\mathrm{A}$ and coagulase gene variability were plotted against the carriage rate, there was no clear relationship between repeat unit number and colonisation index (Fig. 5). Thus, it can be concluded that repeat length variation and variation at the protein level are not strongly involved in colonisation efficacy. The IgG binding assays, relating protein A content to that of the high-producer $S$. aureus Cowan I, revealed 

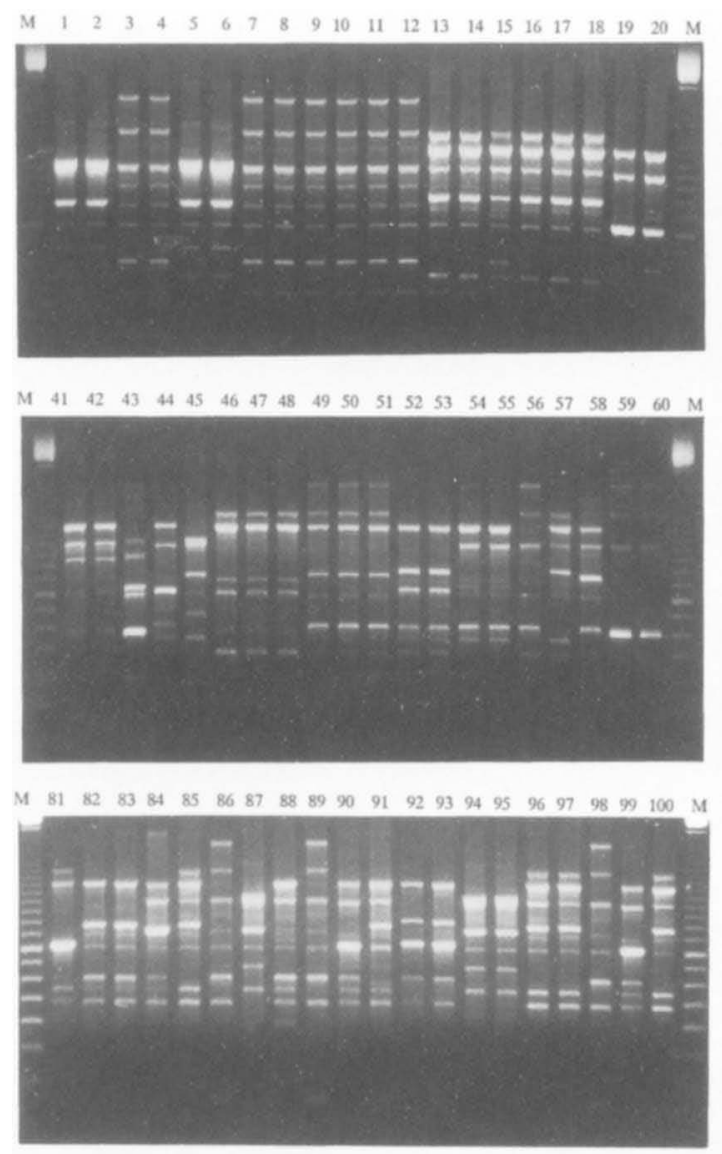
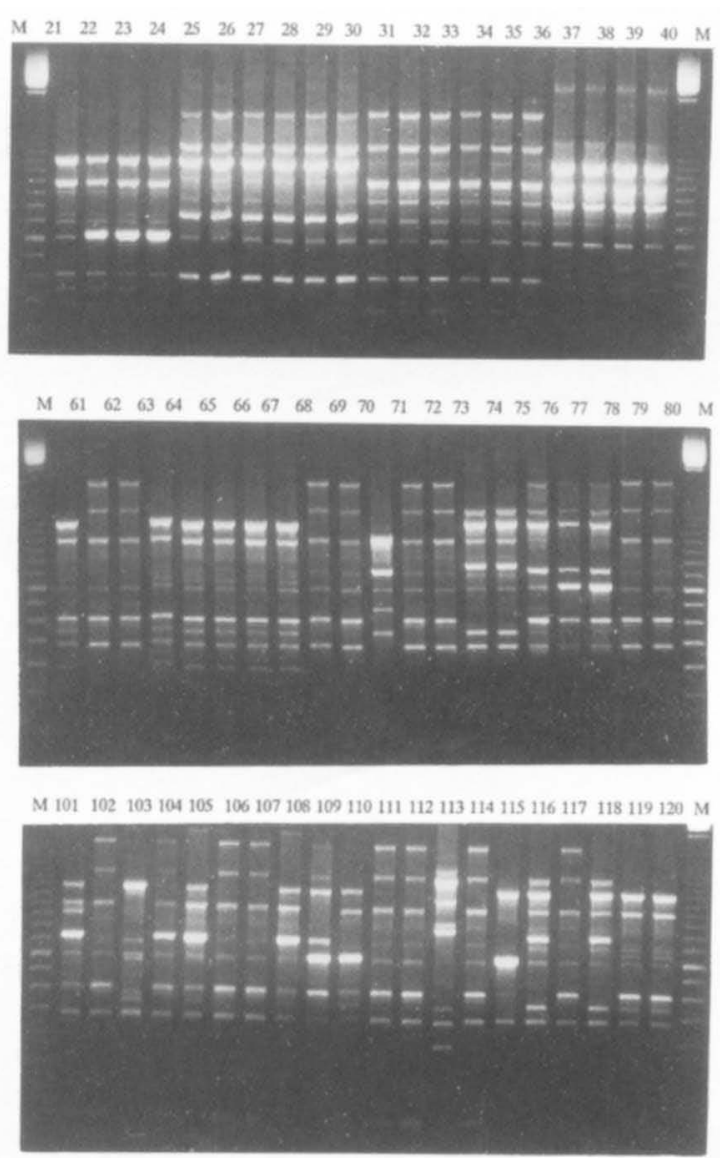

Fig. 1. Survey of the DNA banding patterns obtained by RAPD analysis of $S$. aureus strains collected from persistent, intermittent and incidental nasal carriers. The primer used was the enterobacterial repetitive intergenic consensus sequence ERIC2. Numbering above the lanes corresponds to that given in Table 1 and identifies the carriers as well; in all six panels, mol.wt markers are included in the right and left lanes. The most intensely staining band identifies an 800-bp DNA fragment; all the other fragments differ by an additional 100-bp fragment. Banding patterns have been interpreted by visual inspection; the corresponding codes are presented in Table 1.

a random distribution of protein A activity when compared to the carrier index (Fig. 5b). This confirms the lack of similarity between gene polymorphism and the same carrier state. Moreover, plotting protein A repeat variability against the relative amount of $\operatorname{lgG}$ binding revealed that there was no linear relationship between the two characteristics. A constant number of repeats was accompanied by largely differing IgGbinding coefficients.

\section{Discussion}

The human nasal cavity and especially the anterior nares provide an excellent ecological niche for $S$. aureus. Although varying carriage rates have been documented it is generally assumed that a substantial proportion of the human population harbours $S$. aureus at this particular site. Although large studies were performed in the $1960 \mathrm{~s}$ on the epidemiological behaviour of $S$. aureus [18, 19], there is still little knowledge about the basic determinants of successful long-term colonisation by $S$. aureus and its population dynamics. The human host has shown genetic predis- position to $S$. aureus carriage in some cases [20]. For instance, race or HLA type may influence this [21]. Numerous bacterial components have been implicated in the initial adherence process that leads to successful colonisation of the nasal epithelium, e.g., specific bacterial receptors for surface proteins, including those for collagen [4], fibronectin [5] and fibrinogen [22]. Several of the corresponding genes have been identified, cloned and subjected to mutagenesis. The latter studies indicate a strongly multifactorial nature in adhesion, colonisation and, probably, infection pathways. Bacterial cell-wall components such as the (lipo)teichoic acids are said to be of critical importance in establishing colonisation [23], but, at present, no mechanisms that are involved in persistent or intermittent interaction between host and bacterium have been elucidated.

Table 1 indicates the genetic diversity encountered among $S$. aureus strains isolated from the human nose. Variation can be observed throughout the entire genome by RAPD, but also more localised, large differences in, e.g., repeat numbers, can be seen. In all cases except one, a single strain was encountered, 
Table 2. Comparison of carriage rate and the different number of $S$. aureus phage types and RAPD genotypes detected

\begin{tabular}{|c|c|c|c|c|c|c|c|c|}
\hline \multirow{2}{*}{$\begin{array}{l}\text { Individual } \\
\text { code }\end{array}$} & \multirow{2}{*}{$\begin{array}{l}\text { Carriage } \\
\text { index }\end{array}$} & \multirow{2}{*}{$\begin{array}{c}\text { Number of } \\
\text { strains }\end{array}$} & \multicolumn{2}{|c|}{ Phage types } & \multicolumn{2}{|c|}{ RAPD types } & \multirow{2}{*}{$\begin{array}{l}\text { Number of } \\
\text { phage types/ } \\
100 \text { strains }\end{array}$} & \multirow{2}{*}{$\begin{array}{l}\text { Number of } \\
\text { RAPD types } \\
100 \text { strains }\end{array}$} \\
\hline & & & $\mathrm{n}$ & $\%$ & $\mathrm{n}$ & $\%$ & & \\
\hline A & 10 & 6 & 4 & 66 & 2 & 33 & & \\
\hline B & 10 & 6 & 3 & 50 & 1 & 16 & & \\
\hline $\mathrm{C}$ & 10 & 6 & 3 & 50 & 1 & 16 & & \\
\hline $\mathrm{D}$ & 10 & 6 & 1 & 16 & 1 & 16 & & \\
\hline $\mathrm{E}$ & 10 & 6 & 3 & 50 & 1 & 16 & & \\
\hline $\mathrm{F}$ & 10 & 6 & 2 & 33 & 1 & 16 & & \\
\hline $\mathrm{A}$ & 9 & 6 & 3 & 50 & 1 & 16 & & \\
\hline $\mathrm{B}$ & 9 & 6 & 4 & 66 & 4 & 66 & & \\
\hline $\mathrm{C}$ & 9 & 3 & 1 & 33 & 1 & 33 & & \\
\hline $\mathrm{D}$ & 9 & 2 & 2 & 100 & 1 & 50 & & \\
\hline $\mathrm{E}$ & 9 & 4 & 3 & 75 & 3 & 75 & & \\
\hline \multirow[t]{2}{*}{$\mathrm{F}$} & 9 & 3 & 3 & 100 & 2 & 66 & \multicolumn{2}{|c|}{ Persistent carriers } \\
\hline & & & & & & & 57 & 35 \\
\hline A & 8 & 4 & 4 & 100 & 2 & 50 & & \\
\hline A & 7 & 4 & 3 & 75 & 1 & 25 & & \\
\hline $\mathrm{A}$ & 6 & 4 & 4 & 100 & 2 & 50 & & \\
\hline B & 6 & 4 & 4 & 100 & 3 & 75 & & \\
\hline $\mathrm{C}$ & 6 & 2 & 2 & 100 & 1 & 50 & & \\
\hline $\mathrm{D}$ & 6 & 3 & 2 & 66 & 2 & 66 & \multirow{2}{*}{\multicolumn{2}{|c|}{ Intermittent carriers }} \\
\hline \multirow[t]{2}{*}{$\mathrm{E}$} & 6 & 2 & 2 & 100 & 1 & 50 & & \\
\hline & & & & & & & 92 & 52 \\
\hline A & 5 & 4 & 4 & 100 & 4 & 100 & & \\
\hline B & 5 & 3 & 3 & 100 & 3 & 100 & & \\
\hline $\mathrm{A}$ & 4 & 3 & 3 & 100 & 2 & 66 & & \\
\hline $\mathrm{B}$ & 4 & 3 & 3 & 100 & 2 & 66 & & \\
\hline $\mathrm{C}$ & 4 & 3 & 3 & 100 & 3 & 100 & & \\
\hline $\mathrm{D}$ & 4 & 3 & 3 & 100 & 3 & 100 & & \\
\hline $\mathrm{E}$ & 4 & 3 & 3 & 100 & 3 & 100 & & \\
\hline $\mathrm{F}$ & 4 & 3 & 3 & 100 & 2 & 66 & & \\
\hline A & 3 & 3 & 3 & 100 & 3 & 100 & & \\
\hline B & 3 & 3 & 3 & 100 & 2 & 66 & & \\
\hline C & 3 & 3 & 3 & 100 & 3 & 100 & & \\
\hline \multirow[t]{2}{*}{ D } & 3 & 3 & 3 & 100 & 2 & 66 & Incide & carriers \\
\hline & & & & & & & 100 & 85 \\
\hline
\end{tabular}

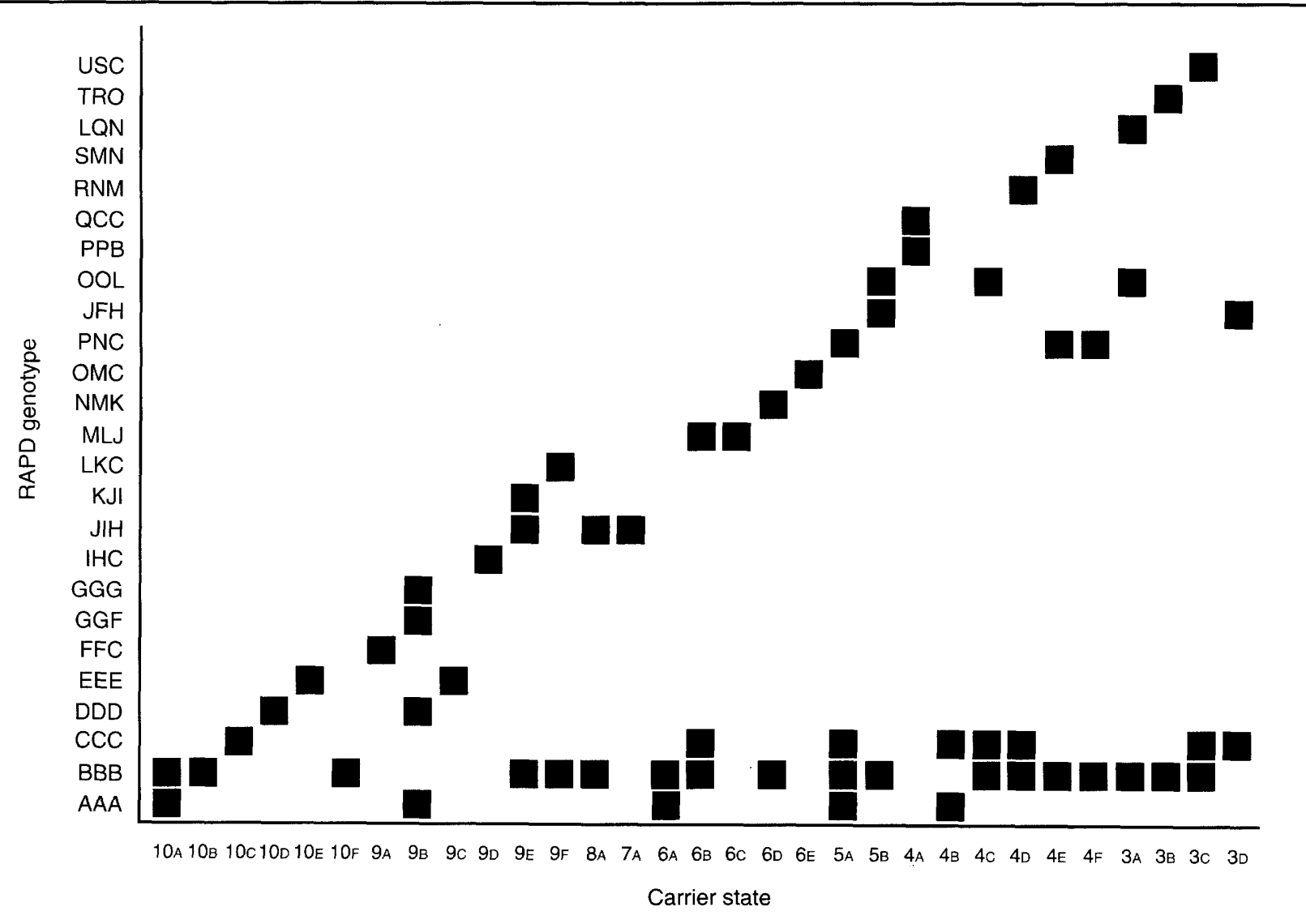

Fig. 2. Plot of RAPD consensus types against individuals with different carriage rates. RAPD type BBB occurs independently of the carriage rate in 17 out of 31 individuals. 

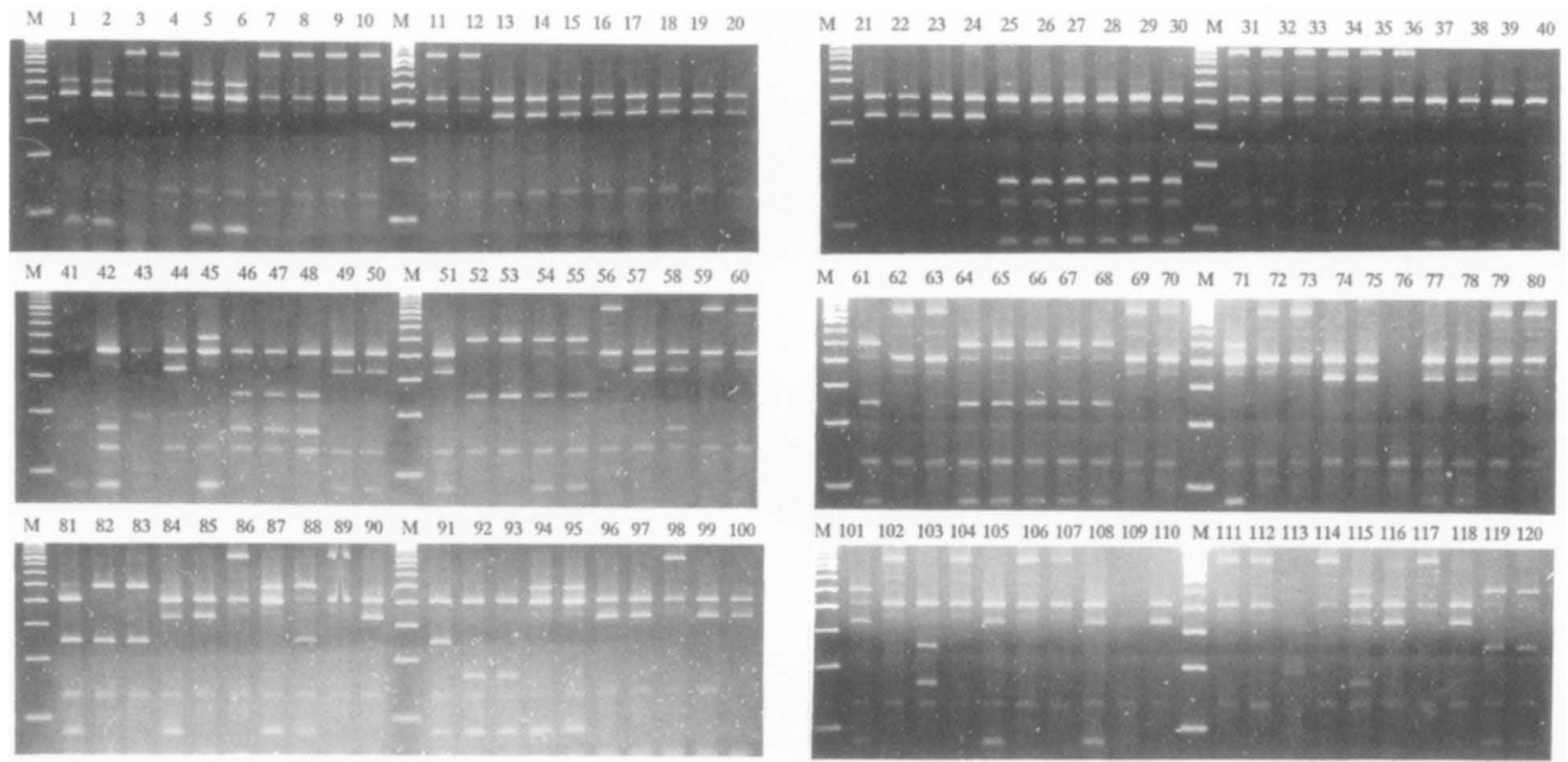

Fig. 3. RFLPs generated by restriction endonuclease analysis of coagulase gene amplicons. Lane numbering corresponds to strain numbers given in Table 1. Mol.wt markers are shown on the left.

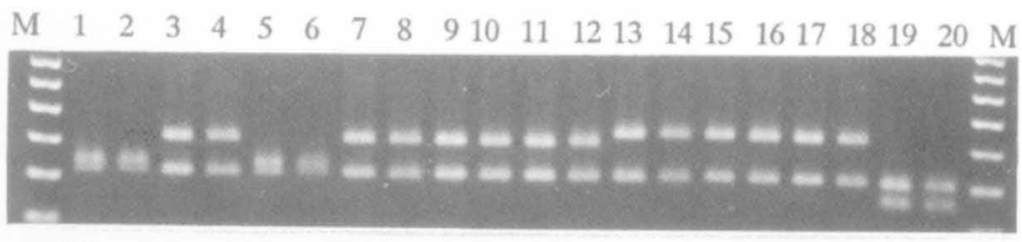

21
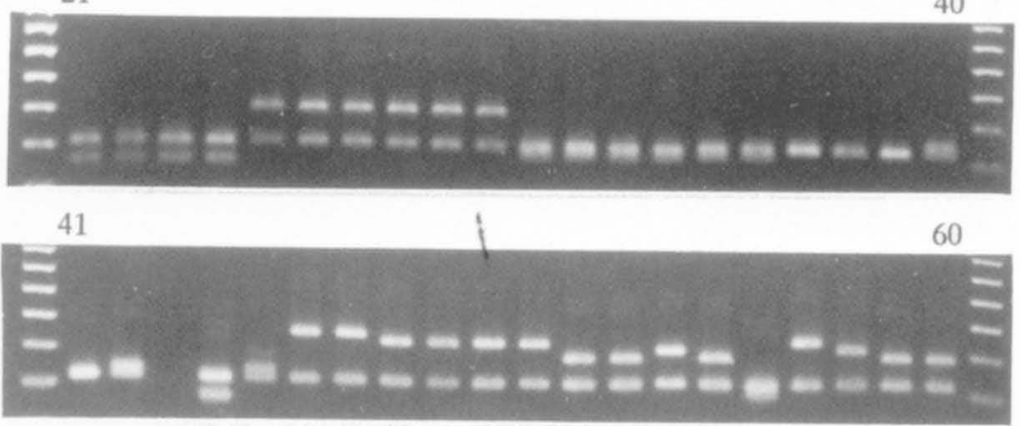

61

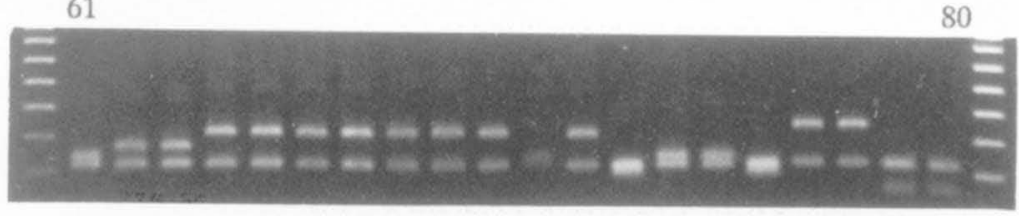

81

100

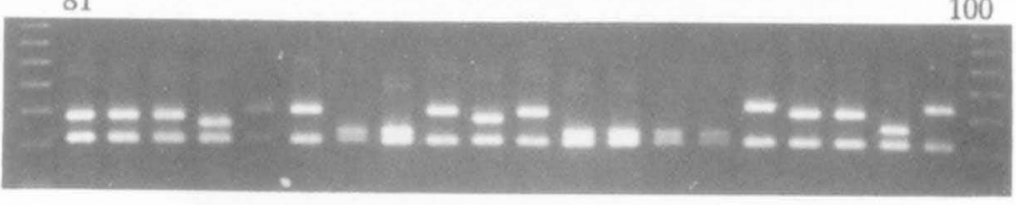

101

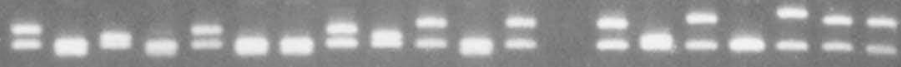

Fig. 4. Survey of protein A gene typing data obtained for the S. aureus strains from individuals demonstrating various carriage indices. Strains are ordered as in Table 1. 
Table 3. Comparison of types identified by RAPD, protein A gene typing and coagulase gene typing

\begin{tabular}{llc}
\hline $\begin{array}{l}\text { RAPD } \\
\text { type }\end{array}$ & $\begin{array}{l}\text { Protein A } \\
\text { gene type }\end{array}$ & $\begin{array}{c}\text { Coagulase } \\
\text { gene type }\end{array}$ \\
\hline AAA & 7 & $12 \mathrm{~A}$ \\
BBB & $3,5-10$ & $14 \mathrm{~B}$ \\
CCC & 7,10 & $9 \mathrm{C}$ \\
DDD & 4 & $9 \mathrm{C}$ \\
EEE & 7,9 & $8 \mathrm{D}, 10 \mathrm{G}$ \\
FFC & 6,7 & $8 \mathrm{D}$ \\
GGF & - & $5 \mathrm{E}$ \\
GGG & 9,10 & $10 \mathrm{~F}$ \\
IHC & 7 & $9 \mathrm{H}$ \\
JHH & $7,8,9$ & $15 \mathrm{I}$ \\
KJI & 9 & $9 \mathrm{C}$ \\
LKC & 8 & $11 \mathrm{~N}$ \\
MLJ & 10 & $10 \mathrm{G}$ \\
NMK & 9 & $9 \mathrm{~J}$ \\
OMC & 9 & $9 \mathrm{H}$ \\
PNC & 8 & $10 \mathrm{G}$ \\
JFH & 7,10 & $10 \mathrm{I}$ \\
OOL & 9 & $9 \mathrm{C}$ \\
PPB & 10 & $9 \mathrm{~J}$ \\
QCC & 7 & $8 \mathrm{D}$ \\
RNM & 8 & $15 \mathrm{I}$ \\
SMH & 7 & $10 \mathrm{~T}$ \\
LQN & 7 & - \\
USC & 7 & $17 \mathrm{C}$ \\
\hline
\end{tabular}

defining single isolate long-term persistency. As most of the strains were genetically distinct, it is not possible to identify any factors in the nose that favour selection of $S$. aureus. It is noteworthy that in the low index carriers putative persistence can sometimes be observed. In individuals $31,15,132,33$ and 11, an identical strain was isolated twice, sometimes years apart (types JFH, BBB, BBB, AAA and QCC, respectively). This means that in $50 \%$ of the lowscore individuals, the lack of persistence as defined by bacterial cultivation may be due to low or variable numbers of bacteria in the nares. On the other hand, it could also be that although multiple types are present, only a single strain is cultured. Table 1 shows three instances of single-day sampling of both nostrils. In one of these, the host was colonised by different strains in different nostrils.

Several bacterial surface proteins are thought to play an important role in the processes of adherence, colonisation and infection [6], e.g., the immunoglobulin $G$ binding protein A [24]. It has been suggested that $\operatorname{IgG}$ binding interferes with bacterial opsonisation [25-27], a feature that would enable evasion of the host immune response by the bacteria. However, the reports on the relevance of protein $A$ expression with regard to virulence or pathogenicity have been contradictory. Where initial data indicated that differences in the level of protein $\mathrm{A}$ production resulted in changes in bacterial virulence [28], later studies failed to confirm this [29]. More recently it has been suggested that variability in the protein $\mathrm{A}$
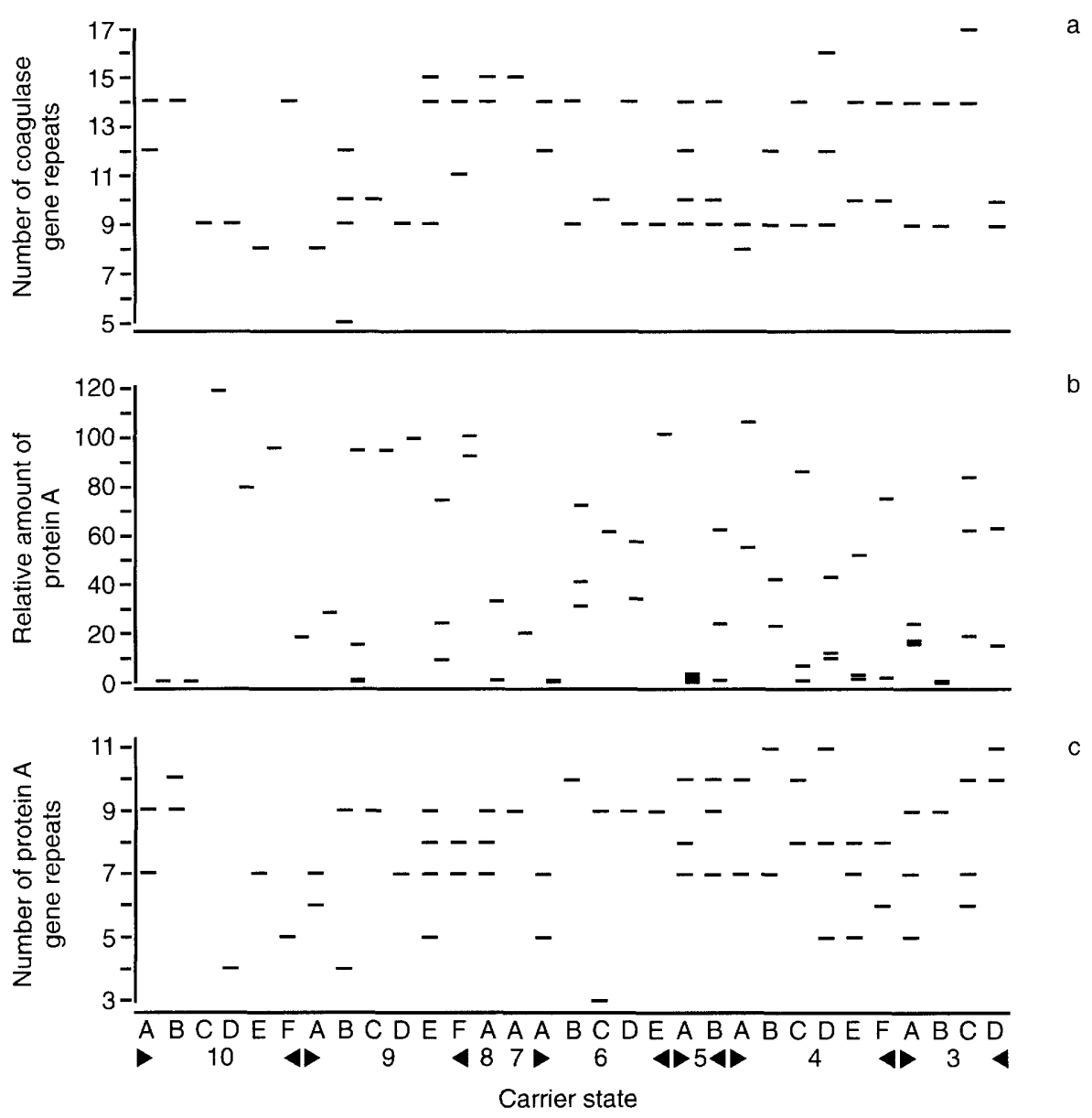

Fig. 5. Schematic overview of repeat unit numbers in the coagulase gene (a), the protein A gene (c) and the relative amount of protein A (b), plotted against the different individuals displaying different carriage rates for $S$. aureus. 
gene repeat region may be correlated with the epidemic behaviour of $S$. aureus strains [16]. The longer the repeat region, the more 'epidemic' a strain would be. This could be due to extended exposure of the immunoglobulin-binding domain and subsequent improvements in immune evasion. In the present study, a similar correlation between the length in protein A gene repeats and persistence of colonisation was shown not to exist. Thus, the hypothesis that larger numbers of repeats may result in improved evasion from the immune system, thereby rendering long-term colonisation more likely, may be incorrect. This is further supported by the fact that there appears to be no linear relationship between the number of repeats and the amount of protein A exposed on the bacterial cell wall. The fact that there is this lack of relationship indicates that it is impossible to predict the biological behaviour imposed by protein A from the number of repetitive moieties present in the encoding gene. In any case, this particular feature does not seem to play a major role in differentiating long-term from short-term nasal carriers of $S$. aureus; or it could be that a large proportion of the strains studied produced extracellular protein $\mathrm{A}$. As the latter is a feature of methicillin-resistant $S$. aureus mainly [30], this is unlikely.

Although conflicting data have been presented in recent literature it is currently believed, based on site directed allele replacement studies [31], that coagulase is probably not a major virulence determinant of $S$. aureus. The repetitive region within the gene is no absolute requirement for prothrombin binding and plasma clotting at the protein level. However, this region may play a role in binding to the bacterial surface. Regarding the structural homologies with similar repeats in protein $A$ and protein $G$ genes, these may be responsible for the strict adherence of a portion of the largely extracellular protein to the cell wall of S. aureus [32]. As such, the quantity of this membrane-bound fraction could depend on repeat unit length. This again could have a direct effect on the way in which the staphylococcal strain interacts with its environment. For this reason, we studied whether or not there was a relationship between persistence of colonisation and the composition of the coagulase gene. As was the case for the protein A gene variability, no such correlation appeared to exist. On the other hand, the data confirmed the usefulness of coagulase gene variation for typing of $S$. aureus strains $[17,33]$.

It has been demonstrated recently that the incidence of isolation of $S$. aureus phage type 95 has increased to $20 \%$ of the total number of S. aureus strains from human clinical material in the Danish population [34]. In the present study, it was shown that this particular type was present in over $50 \%$ of the subjects. The putative clonal nature of this strain, which is resistant to penicillin only, was confirmed by the data obtained by RAPD studies. All the isolates of phage type 95 belonged to RAPD type BBB, indicating true genetic homogeneity, irrespective of the fact that within the protein A genes of these strains variable repeat numbers can be determined.

In summary, the results of phage typing and RAPD analysis in this study could not demonstrate any common genetic or phenetic elements in defined groups of nasal $S$. aureus carriers. Genetic variation in two genes encoding proteins exposed outside the staphylococcal cell does not seem to contribute to variation in persistence; this was confirmed by the phenotypic analysis of the gene product of one of these two.

We greatly appreciate the help of $\mathrm{Dr} \mathrm{V}$. T. Rosdahl in the phage typing studies.

\section{References}

1. Kluytmans JAJW, Mouton JW, ljzerman EPF et al. Nasal carriage of Staphylococcus aureus as a major risk factor for wound infections after cardiac surgery. J Infect Dis 1995; 171: 216-219.

2. Nelson RM, Dries DJ. The economic implications of infections in cardiac surgery. Ann Thorac Surg 1986; 42: 240-246.

3. Kluytmans JAJW, Mouton JW, Maat APWM, Manders MAAJ, Michel MF, Wagenvoort JHT. Surveillance of postoperative infections in thoracic surgery. J Hosp Infect 1994; 27: $139-147$.

4. Patti JM, Jonsson H, Guss B et al. Molecular characterization and expression of a gene encoding a Staphylococcus aureus collagen adhesin. J Biol Chem 1992; 267: 4766-4772.

5. Flock JI, Froman G, Jonsson $\mathrm{K}$ et al. Cloning and expression of the gene for a fibronectin-binding protein from Staphylococcus aureus. EMBO J 1987; 6: 2351-2357.

6. Foster TJ, McDevitt D. Surface-associated proteins of Staphylococcus aureus: their possible roles in virulence. FEMS Microbiol Letts 1994; 118: 199-206.

7. Eriksen NHR, Espersen F, Rosdahl VT, Jensen K. Carriage of Staphylococcus aureus among 104 healthy persons during a 19-months period. Epidemiol Infect 1995; 115: 51-60.

8. Eriksen NHR, Espersen F, Rosdahl VT, Jensen K. Evaluation of methods for the detection of nasal carriage of Staphylococcus aureus. APMIS 1994; 102: 407-412.

9. Korner B. Storage of gonococci in solid Stuart's medium. In: Proceedings of the Northern Dermatological Society 162. Lund, Hakon Ohlsson Boktryckeri. 1963: 45-48.

10. Blair JE, Williams REO. Phage typing of staphylococci. Bult World Health Organ 1961; 24: 771-784.

11. Parker MT. The significance of phage-typing patterns in Staphylococcus aureus. In: Easmon CSF, Adlam C (eds) Staphylococci and staphylococcal infections, vol 1; Clinical and epidemiological aspects. London, Academic Press, 1983: $33-62$.

12. Boom R, Sol CJA, Salimans MMM, Jansen CL, Wertheim-van Dillen PME, van der Noordaa J. Rapid and simple method for purification of nucleic acids. J Clin Microbiol 1990; 28: 495-503.

13. van Belkum A, Bax R, Prevost G. Comparison of four genotyping assays for epidemiological study of methicillin resistant Staphylococcus aureus. Eur J Clin Microbiol Infect Dis 1994; 13: 420-424.

14. van Belkum A, Bax R, Peerbooms P, Goessens WHF, van Leeuwen N, Quint WGV. Comparison of phage typing and DNA fingerprinting by polymerase chain reaction for discrimination of methicillin-resistant Staphylococcus aureus strains. J Clin Microbiol 1993; 31: 798-803.

15. Versalovic J, Koeuth T, Lupski JR. Distribution of repetitive DNA sequences in eubacteria and application to fingerprinting of bacterial genomes. Nucleic Acids Res 1991; 19: 6823-6831. 
16. Frenay HM, Theelen JPG, Schouls LM et al. Discrimination of epidemic and nonepidemic strains of methicillin-resistant Staphylococcus aureus strains on the basis of protein A gene polymorphism. I Clin Microbiol 1994; 32: 846-847.

17. Goh S-H, Byrne SK, Zhang JL, Chow AW. Molecular typing of Staphylococcus aureus on the basis of coagulase gene polymorphisms. J Clin Microbiol 1992; 30: 1642-1645.

18. Williams REO. Healthy carriage of $S$. aureus: its prevelance and importance. Bacteriol Rev 1963; 27: 56-71.

19. Weinstein HJ. The relation between the nasal-staphylococcalcarrier state and the incidence of postoperative complications. $N$ Engl $J$ Med 1959; 260: 1303-1308.

20. Millian SJ, Baldwin JN, Rheins MS, Weiser HH. Studies on the incidence of coagulase-positive staphylococci in a normal unconfined population. Am J Publ Health 1960; 50: $791-789$.

21. Rountree PM. Staphylococci harboured by people in Western highlands of New Guinea. Lancet 1956: 719-720.

22. Foster TJ, Greene C, McDevitt D. Fibronectin and fibrinogen binding proteins of $S$. aureus. Third International Meeting on Bacterial Epidemiological Markers, Cambridge. 1994: Abstract no. L26.

23. Baddiley J, Buchanan JG, Rajhandary UL, Sanderson AR. Teichoic acid from the walls of Staphylococcus aureus 4: structure of the $\mathrm{N}$-acetylglucosaminylribitol residues. Biochem J 1962; 82: 439-448.

24. Haagen IA, Heezius HC, Verkooyen RP, Verhoef J, Verbrugh HA. Adherence of peritonitis-causing staphylococci to human peritoneal mesothelia cell monolayers. J Infect Dis 1990; 161: 266-273.

25. Gemmell CG, Tree R, Patel A, O'Reilly M, Foster TJ. Susceptibility to opsonophagocytosis of protein A, alphahemolysin and beta-toxin deficient mutants of $S$. aureus isolated by allele-replacement. In: Jeljaszewicz J, Ciborowski P (eds)
The staphylococci. Zentralbl Bakteriol 1991; Suppl 21: $273-$ 277.

26. Peterson PK, Verhoef J, Sabath LD, Quie PG. Effect of protein A on staphylococcal opsonization. Infect Immun 1977; 15: $760-764$.

27. Spika JS, Verbrugh HA, Verhoef J. Protein A effect on alternative pathway complement activation and opsonization of Staphylococcus aureus. Infect Immun 1981; 34: 455-460.

28. Patel AH, Nowlan P, Weavers ED, Foster TJ. Virulence of protein A-deficient and alpha-toxin-deficient mutants of Staphylococcus aureus isolated by allele replacement. Infect Immun 1987; 55: 3103-3110.

29. Jonsson P, Lindberg M, Haraldsson I, Wadström T. Virulence of Staphylococcus aureus in a mouse mastitis model: studies of alpha-hemolysin, coagulase, and protein $\mathrm{A}$ as possible virulence determinants with protoplast fusion and gene cloning. Infect Immun 1985; 49: 765-769.

30. Uhlen M, Guss B, Nilsson B, Götz F, Lindberg M. Expression of the gene encoding protein A in Staphylococcus aureus and coagulase-negative staphylococci. J Bacteriol 1984; 159: 713 719.

31. Phonimdaeng P, O'Reilly M, Nowlan P, Bramley AJ, Foster TJ. The coagulase of Staphylococcus aureus 8325-4. Sequence analysis and virulence of site-specific coagulase-deficient mutants. Mol Microbiol 1990; 4: 393-404.

32. Bodén MK, Flock J-I. Fibrinogen-binding protein/clumping factor from Staphylococcus aureus. Infect Immun 1989; 57: 2358-2363.

33. Schwarzkopf A, Karch H. Genetic variation in Staphylococcus aureus coagulase: potential and limits for use as epidemiological marker. J Clin Microbiol 1994; 32: 2407-2412.

34. Rosdahl VT, Witte W, Musser M, Jarløv JO. Staphylococcus aureus strains of type 95 . Spread of a single clone. Epidemiol Infect 1994; 113: 463-470. 